\title{
Peons and Progressives: Race and Boosterism in the Lower Rio Grande Valley, 1904-1941
}

\author{
Cory Wimberly, Javier Martínez, David Muñoz, and \\ Margarita Cavazos
}

This article focuses on the discourse of race produced by boosters in the Lower Rio Grande Valley (LRGV) of Texas; it builds on previous research showing the effects of booster materials on the conduct and perception of immigrants. Today, the LRGV continues to impact issues and debates about race in the United States; as such, it is imperative to offer a critical eye to the discourses and mythologies that frame race in the region. A discursive analysis of race in booster materials shows that race was not just an isolated element but one that deeply shaped almost every aspect of the construcion of placefrom land, to beauty, to policing.

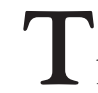

he history of the U.S.-Mexico borderlands

has garnered increasing attention in the past decade. ${ }^{1}$ Borderlands writers who were once obscure, like the Chicana feminist Gloria E. Anzaldúa, are now common points of reference among an ever-widening group of scholars. A diversity of historical

CORY WIMBERLY is an associate professor of philosophy at the University of Texas Rio Grande Valley. He works in social and political philosophy with a specialty in propaganda and public relations.

JAVIER MARTíneZ recently graduated with a Bachelor of Arts in philosophy from the University of Texas Rio Grande Valley. He has enlisted for two years with the Peace Corps and aspires to begin graduate school soon after.

DAVID MUÑOZ is a graduate from the University of Texas Rio Grande Valley, earning his Bachelor of Arts in political science and philosophy. He hopes to find a long-lasting career with a non-profit organization.

Margarita Cavazos is an undergraduate student of philosophy at the University of Texas Rio Grande Valley. She is currently a student learning assistant for humanities at South Texas College.

${ }^{1}$ For example, two works that discuss the growing literature on the borderlands include Tim Bowman, "Negotiating Conquest: Internal Colonialism and Shared Histories in the South Texas Borderlands," Western Historical Quarterly 46 (Autumn 2015): 335-53 and Pekka Hämäläinen and Samuel Truett, "On Borderlands," Journal of American History 96 (September 2011):338-61. 
approaches including transnational, decolonial, and social perspectives has been used to grapple with the complex set of relations that mark South Texas and the borderlands more generally. Although increasing attention from a widening array of perspectives has been focused on the history of this region, there are still many primary sources that are underutilized or undertheorized in the current scholarship. ${ }^{2}$

This article makes use of such primary sources by examining the promotional land sales materials from deep South Texas now housed at the University of Texas Rio Grande Valley, the University of North Texas, and the Museum of South Texas History in Edinburg, Texas. These promotional materials were produced by land developers in order to entice northern farmers to move to the Lower Rio Grande Valley (LRGV) of South Texas.

Historians have documented the impact that the promotional materials, both in the LRGV and across the West, had on immigrants' and existing residents' attitudes and actions. In the only other article focused solely on the land booster materials from the LRGV, Christian Brannstrom and Matthew Neuman focus on detailing how the materials worked to construct a "place-myth." They define a place-myth as a "discourse" that "legitimize[s] social practices that alter the material landscape." 3 Brannstrom and Neuman make the argument that the promotional materials "legitimized" new conduct that transformed the LRGV in a deep and pervasive way. In a recent book, Timothy Bowman agrees that the promotional materials aimed to "construc[t] an imagined future for the region's new inhabitants," again emphasizing the transformative impact of booster materials. ${ }^{4}$ David Wrobel, looking through a larger geographical lens, writes in Promised Lands that promotional materials across the West had the function of shaping people's conduct and attitudes, especially in relation to race: "the promotional genre both reflected and, because of its pervasiveness helped shape the racial attitudes of the white majority." ${ }^{5}$ Wrobel further concludes that the promotional materials "surely played an important part in shaping people's perceptions

${ }^{2}$ Few works have their primary focus on promotional materials. Some of the few examples include Christian Brannstrom and Matthew Neuman, "Inventing the 'Magic Valley' of South Texas, 1905-1941," Geographical Review 99 (April 2009): 123-45 and S. Zulema Silva-Bewley, The Legacy of John H. Shary: Promotion and Land Development in Hidalgo County, South Texas 1912-1930 (Edinburg, TX: University of Texas-Pan American Press, 2001). Increasingly, more work is citing promotional materials to support its arguments. Current examples include Bowman, "Negotiating Conquest," 3446. Timothy Bowman, Blood Oranges: Colonialism and Agriculture in the South Texas Borderlands (College Station: Texas A\&M University Press, 2016) and Alicia M. Dewey, Pesos and Dollars: Entrepreneurs in the Texas-Mexico Borderlands, 1880-1940 (College Station: Texas A\&M University Press, 2014), 84-94.

3 Jeffrey Sasha Davis, "Representing Place: 'Deserted Isles' and the Reproduction of Bikini Atoll," Annals of the Association of American Geographers 95 (September 2005): 607-25 quoted in Brannstrom and Neuman, 125.

${ }^{4}$ Bowman, Blood Oranges, 53-4.

${ }^{5}$ David M. Wrobel, Promised Lands: Promotion, Memory, and the Creation of the American West (Lawrence: University Press of Kansas, 2002), 15. 
of the West." 6 Terry Jordan offers some empirical evidence of the effectiveness of land boosters' propaganda to shape conduct in a 1978 survey administered to 3,860 residents of the LRGV. In Perceptual Regions in Texas, Jordan finds that in the counties of deep South Texas the "spatial perception of average people" still follows the contours of the "vernacular region" promoted by the boosters. ${ }^{7}$

The aim of this article is not to duplicate existing research demonstrating the importance of booster materials within the LRGV and across the West for shaping peoples' conduct, relationships, and understanding of place; instead, it begins with it. If booster materials are as impactful as has been widely argued, then these materials merit deep reflection and analysis about exactly what kind of discourse they are producing. This article hones in on the discourse on race produced in the booster materials of the LRGV from 1904 to 1941 and traces not only their construction of race but also how raced ideas permeated the entirety of the sense of place given to the LRGV. This topic is important, not only for filling in the accounts of Wrobel and Bowman, but also because of the ongoing and outsized impact that the racial attitudes of the LRGV have on the national stage. Just recently the "migrant crises" of 2014 and 2015 were played out in the national media from reporting based in the LRGV, today much of the human drama surrounding the Deferred Action for Childhood Arrivals policy (DACA) is being staged out there, and the first sections of the border wall that President Donald Trump proposes to build are slated for a wildlife refuge squarely in the center of the LRGV. ${ }^{8}$ While many areas of the United States are important for the formation of national attitudes about race, the LRGV is certainly notable among them and worthy of close attention - especially in the case of Latino race and identity.

Brannstrom and Neuman's "Inventing the 'Magic Valley" generates important insights about the promotional material and its impact on the LRGV, but their work also has significant shortcomings. In particular, Brannstrom and Neuman are surprisingly shy on the issue of race, never using the term "racism" and only once offering up the term "[h]ispanophobia" to describe the systematic forms of racial oppression imagined in

6 Ibid., 10.

7 Terry G. Jordan, "Perceptual Regions in Texas," Geographical Review 68 (July 1978): 293.

${ }^{8}$ Markon, Jerry and Joshua Partlow, "Unaccompanied children crossing southern border in greater numbers again, raising fears of new migrant crisis," Washington Post, 16 December 2015, https:/www.washingtonpost.com/news/federal-eye/wp/2015/12/16/unaccompanied-children-crossingsouthern-border-in-greater-numbers-again-raising-fears-of-new-migrant-crisis/?utm_term=.

84681d8aaebc; Angilee Shah, "DACA Recipients Won't Go Back into the Shadows Quietly," Public Radio International, 5 September 2017, https://www.pri.org/stories/2017-08-30/daca-recipients-won-tgo-back-shadows-quietly; Michael Hardy, "In South Texas, Threat of Border Wall Unites Naturalists and Politicians," New York Times, 13 August 2017, https://www.nytimes.com/2017/08/13/us/in-southtexas-threat-of-border-wall-unites-naturalists-and-politicians.html. Since this article was submitted, the issue of the separation of children and adults in migrant families also erupted in the Rio Grande Valley: Michael E. Miller, "Family separations could double says Border Patrol chief in Rio Grande Valley," The Washington Post, 16 June 2018, https://wapo.st/2yj63KC?tid=ss_mail\&utm_term=. a2b63a4c7a79. 
the promotional materials. Translating "Hispanophobia" into plain language-_efear of Spanish speakers"- shows just how beside the point and inaccurate this term is to describe race relations in the early twentieth-century United States. As Anzaldúa herself wrote as a person from the LRGV about the ties of language to identity, "Ethnic identity is twin skin to linguistic identity-I am my language." " Linguistic discrimination, even if that was the only form of discrimination present in the LRGV, is never only about language but about crafting a systematic means of oppression tied to race. ${ }^{10}$

Bowman's more recent work in Blood Oranges is a significant step forward in the analysis of the promotional materials. He is much more sensitive to the politics of the promotional material and rightly finds race to be a core part of its "imagined future":

Notions of themselves as neopioneering farmers wringing profit from the backs of Mexican laborers in a modern agribusiness sector would inform Anglos' ideas of collective self-identity and race relations in the Valley and South Texas for decades. Much of the well-documented maltreatment of ethnic Mexicans in the region stemmed directly from and became systematized through the king-sized profit motives of early South Texas growers as sold to them by local boosters. ${ }^{11}$

Bowman's work on race focuses on Mexicans as subservient labor to create wealth for Anglo farmers. His frame of analysis is the colonial model and, while relevant, leads to racial discourse serving as only concomitant to profit-making. Bowman states that for growers "[a]ll other considerations remained secondary" to profit. ${ }^{12}$ While our conclusions are broadly complementary, we find that race structures social relations in ways not reducible to labor and profit, although they remained a central motivation.

The primary perspective this article takes is that of discursive analysis, particularly as developed in the Essex school by Ernesto Laclau and Chantal Mouffe. Discourse analysis in this vein takes the identities established in any discourse — for instance, racial and economic identities - to be the result of "a relation among elements."13 Taking identities as relational rather than as primary kinds means that identity is produced not by a natural inhering essence but through the mutual positioning of the different elements to one another. A discourse is the set of such relationships between

${ }^{9}$ Gloria E. Anzaldúa, "How to Tame a Wild Tongue," in Borderlands / La Frontera: The New Mestiza (San Francisco: Aunt Lute Books, 1987), 53-64.

10 John Metta, "It's Not About Race! Why Do Black People Think Everything is About Race?," Those People, last modified 18 September 2016, https://www.thsppl.com/thsppl-articles/2017/4/20/itsnot-about-race-1.

${ }^{11}$ Bowman, Blood Oranges, 54.

12 Ibid., 2.

${ }^{13}$ Ernesto Laclau and Chantal Mouffe, Hegemony and Socialists Strategy: Towards a Radical Democratic Politics (London: Verso, 1985), 105. 
elements that is productive of their identities; it is the larger system of interconnected identities. ${ }^{14}$ In the promotional materials, race is an important element in defining the creation of the identity of the other elements in the discourse such as nature, civilization, leisure, order, and morality. Jason Pierce, in Making the White Man's West, notes that it was common in booster materials across the West for race to play an important role in the formation of identity for place and self. ${ }^{15}$ Matthew Stanley, in The Loyal West, makes the more specific argument that race and racism served as a point of unification after the Civil War for Whites in Middle America, especially in the Midwestern states that served as a the base of recruitment for the LRGV. ${ }^{16}$ This article will trace out the discursive relationships productive of identity in the booster materials, with a focus on the role of race. The impact of race on the discourse of place-the "place-myth" — will be discussed in comparison with booster materials from other areas across the West.

The article's first section examines the relations through which "the Mexican" was produced in the promotional materials of the LRGV. The booster materials produced a deep equivalence between the Mexicans inhabiting the region and the natural environment in which they lived. The result was that the equivalence between the Mexican and nature was so deep that the Mexican was reduced to one of the natural features of the area, who could be legitimately exploited in the same way as the other features of the area, like the plants, animals, land, and water.

The second section provides an abbreviated connection between the first and third. This section explores how the racial discourse developed in the first section was established in the context of labor. While Brannstrom and Neuman, Bowman, Dewey, and others have recognized how Mexicans have figured in the booster literature as a source of cheap labor, there is more to the way that Mexicans were figured as labor than has yet been revealed. ${ }^{17}$ More specifically, as Mexicans mirrored the land and nature of the LRGV in their essential qualities, so too did the strategies of exploitation mirror those of the land and nature. The booster propaganda proposed the same types of subjugation for the land, the vegetation, and the river as it proposed for the Mexican, encompassing them all as part of the natural resources of the LRGV.

The last section plows new ground and deals with racial segregation in leisure and other aspects of life outside of labor. The promotional materials aimed to show that newcomers would be able to participate in social institutions comprising "people [who] are generally of a class that have been successful in the North-people with means,

14 Ibid., 105.

${ }^{15}$ Jason E. Pierce, Making the White Man's West: Whiteness and the Creation of the American West (Boulder: University Press of Colorado, 2016), 152.

${ }^{16}$ Matthew E. Stanley, The Loyal West: Civil War and Reunion in Middle America (Chicago: University of Illinois Press, 2017).

${ }^{17}$ Brannstrom and Neuman, "Inventing the "Magic Valley," 129; Dewey, Pesos and Dollars, 86. 
who have been used to the best of society." 18 The literature promised northern immigrants their own institutions of worship and schooling for their children, their own social events, and their own leisure and sporting activities. Moreover, significant emphasis was placed on the reconstruction of the institutions of policing and justice in order to ensure would-be land purchasers that the necessary force was present to safeguard the immigrants' privilege in all aspects of life. This third and final section draws out clearly the implications of the first two sections: namely, that race is a key element of the promotional discourse whose impact extends well beyond the justification of exploitative relations of labor.

Before we turn to direct consideration of the promotional materials, it is important to set the context in which they appeared. The LRGV is comprised roughly of the land that lies along the Rio Grande from where it empties into the Gulf of Mexico to about 100 miles inland. This land did not become part of the United States until the 1848 Treaty of Guadalupe Hidalgo. Almost immediately after the treaty, frictions arose between the influx of Anglo settlers and the local ethnically Mexican population. During the transfer of land titles from Mexico to the United States, some of these northern immigrants used what Armando Lazano refers to as "devious means" to expropriate land from its previous Mexican landowners. ${ }^{19}$ Although tensions often ran high between Anglos and Mexicans, it would be wrong to suggest that something like the racial segregation that later characterized the area became the norm in the nineteenth century. From 1848-1870, Tejano stock raisers dominated the region, and there were many partnerships between Anglos and Tejanos. ${ }^{20}$ In the mid- and late nineteenth century, the incoming northerners were frequently men of means, who bought land in South Texas and often married the daughters of elite local Tejano landowners. The children of these marriages served as a bridge between communities as they were familiar with both cultures and languages. ${ }^{21}$

It was this mixed group of wealthy local landowners that worked to bring a railroad line to South Texas in $1904 . .^{22}$ They rightly figured that the ability to transport produce out of the area to the northern markets of the United States would raise land values and create an opportunity to profit more from farming and land sales than they

18 Jackson-Vreeland Land Co., The True Story of the Lower Rio Grande Valley, Texas, 1914, Box 2, Rio Grande Valley Promotional Literature Collection, Library Archives and Special Collections, The University of Texas Rio Grande Valley (hereafter Rio Grande Valley Promotional Literature Collection).

${ }^{19}$ Armando C. Lozano, Tejano Legacy: Ranchers and Settlers in South Texas, 1734-1900 (Albuquerque: University of New Mexico Press, 1998), 145.

20 Ibid., 189-90.

${ }^{21}$ Benjamin Heber Johnson, Revolution in Texas: How a Forgotten Rebellion and Its Bloody Suppression Turned Mexicans into Americans (New Haven: Yale University Press, 2003), 13-4; Pierce, Making the White Man's West, 154.

22 Dewey, Pesos and Dollars, 46-53; David Montejano, Anglos and Mexicans in the Making of Texas, 1836-1986 (Austin: University of Texas Press, 1987), 107-13; Johnson, Revolution in Texas, 26-37. 
were profiting from ranching. There was nothing new about this partnership of railroads and wealthy landowners - western lands had been promoted and sold this way since at least the 1850s. ${ }^{23}$ The introduction of the St. Louis, Brownsville, and Mexico Railway (SBM) on July 4, 1904, brought the results expected: farm produce began to be exported in great amounts, wealthy ranchers began to sell off their newly subdivided land, and developers profited off of pumping stations and the sales of irrigation services. The immediate losers were the poor Mexican subsistence ranchers who could not make enough money ranching to pay the taxes on the ever-increasing property valuations; Dewey writes that "[t]he ranchos of Hidalgo county were virtually all gone by 1920." 24

Even dispossession due to tax delinquency or sales due to imminent dispossession was not fast enough to provide new lands for the arriving "colonist." 25 Some of these so-called colonists began squatting on the land of the poor ranchers; Johnson writes that "The growing value of real estate prompted some to resort to the simple expedient of occupying a desired tract and violently expelling the previous occupants." 26 The use of violence in the LRGV to acquire land was shared with other regions across the West; as Pierce notes bluntly, "Violence therefore provided the most powerful tool for marginalizing non-white peoples and protecting the white man's West."27 Natalia Molina sees this process as an extension of manifest destiny, which "is inherently a racial ideology that pivots on ideas of who is deemed worthy of access to resources and fit for citizenship." 28 The immediate problem for the poor ranchers was that they were too cash poor to hire lawyers to evict the squatters so the choice for them was to lose the land to outright theft or to sell it to pay the legal bills. In the end, the victory was the same for the northerners who either squatted on the land illegally or purchased it from the rancher to pay the legal bill against another squatter cum colonist. ${ }^{29}$

Jovita Gonzalez, a resident at the time, called this an "American invasion," in which Tejanos found themselves "segregated into their own quarters." 30 Extant research has already documented that the northern farmers recruited to South Texas by the land sales materials formed the most vocal and violent wing of South Texas

23 Wrobel, Promised Lands, 20.

${ }^{24}$ Dewey, Pesos and Dollars, 140.

25 John H. Shary, The Golden Story of Sharyland, 1941, Box 1, Rio Grande Valley Promotional Literature Collection, $1 \& 9$.

26 Johnson, Revolution in Texas, 33.

27 Pierce, Making the White Man's West, 209.

${ }^{28}$ Natalia Molina, "The Long Arc of Dispossession: Racial Capitalism and Contested Notions of Citizenship in the U.S.-Mexico Borderlands in the Early Twentieth Century," Western Historical Quarterly 45 (Winter 2014): 441.

29 Johnson, Revolution in Texas, 33.

30 Jovita Gonzalez, "America Invades the Border Towns," Southwest Review 15 (Summer 1930): 469-70 quoted in Montejano, Anglos and Mexicans, 113. 
residents who, as one local Tejano leader critically remarked, "wanted 'Mexicans' as farm labor and nothing else." 31 The wealthy Mexican ranchers and businessmen that helped fund the railway had serious regrets and many fell in with the anger and frustration common among Tejanos. These developments were not just humiliating to poor Mexican ranchers who lost their lands but also to the wealthy Mexican elite who, regardless of their wealth, were lumped in with the undifferentiated group, "Mexicans" by the newly arriving Anglo farmers. None of the promotional materials at the University of Texas Rio Grande Valley referenced the upper class of Tejanos and Mexican nationals who lived in and frequented the area, nor did they significantly differentiate Tejanos from Mexican nationals. While such a distinction was present in fact, it did not form a part of the booster discourse. In 1914, the regional newspaper Regeneración told its oppressed and infuriated audience that "A day will come when the mesquite trees of the state will hang with the bodies of the white bandits... who have denied the Mexican the right to life in this savage state of the south." ${ }^{2}$

All through the early decades of the twentieth century, land continued to be sold to incoming White farmers and segregation intensified. The Ku Klux Klan grew popular in the Valley in the 1920s and by the 1930s, the schools were 90 percent segregated, and commercial establishments with No Mexicans signs were ubiquitous. ${ }^{33}$ This result was not inevitable; until the SBM railroad came to South Texas and with it hordes of Anglos looking to establish a racially segregated society, relations between Anglos and Tejanos had proceeded on better if not ideal terms. Instead, what happened was a reimagining of race relations, similar in many ways to Jim Crow segregation, a kind of segregation that has elsewhere been referred to as "Juan Crow." 34 The inculcation of this segregated vision in immigrants through the promotional materials and land boosters was key to its establishment.

Before we enter into the analysis of the materials to further develop the important notion of race there, it is important to clarify the racial language used in this article. As noted previously, the promotional literature made no distinction between Tejanos - who were citizens of the United States and thus entitled to the same benefits and protections as Anglos-and immigrants from Mexico who came to work. Likewise, no difference was recognized between the families descended from the Spaniards who settled the area through land grants and the indigenous people of Mexico who were frequently their subjugated labor. The historian David Montejano writes that "In the rural society these commercial farmers were creating, there were no longer any significant differences between the displaced 'Spanish' elite and the

31 Johnson, Revolution in Texas, 177.

32 “A los hijo de Cuahtémoc, Hidalgo y Juárez en Texas," Regeneración, 24 January 1914, quoted in Johnson, Revolution in Texas, 37.

33 Johnson, Revolution in Texas, 178.

34 José Jorge Mendoza, "Doing Away with Juan Crow: Two Standards for Just Immigration Reform,” APA Newsletter on Hispanic/Latino Issues in Philosophy 15, no. 2 (2015): 14-9. 
landless 'Mexican.' Now a Mexican was simply a Mexican.”35 Montejano's general summary of local Anglo attitudes is echoed in the promotional materials. Although there were certainly important social and economic differences in the LRGV between Tejanos and Mexican nationals, the wealthy and the poor, European descendants and Indigenous peoples, these were not visible in the booster literature. There were a number of euphemisms used in the literature for Mexicans_ "primitive," "quaint and plebian," "Peons," "goat herders," "gleaners," "cheap" and "satisfactory labor"-but these terms were not meant to mark different people but to note the qualities of an undifferentiated lot. ${ }^{36}$

As Wrobel demonstrates in the booster literature from the wider West, race was a sensitive topic in land sales. At the same time that the boosters wanted to reaffirm the economic benefits of living with those considered inferior, they also wanted to allay European Americans' fears of living with the racial other. ${ }^{37}$ Race had to be emphasized but not too much and in careful terms. What is unique about the materials from the LRGV as compared to almost every other area Wrobel discusses in the West is the uniformity of its racial vision and its vastly simplified binary system of race. Unlike California, for instance, where boosters spoke with a multiplicity of perspectives about Indians, Mexicans, Blacks, Chinese, and the various types of European Americans, the materials from the LRGV largely just acknowledge two groups, most commonly referred to as "Mexicans" and "Northerners" and speak with a more homogeneous perspective about race. This typology is not just unusual for the way in which it simplified the category of racial other but also for the way that it simplified what it meant to be part of the privileged racial caste. ${ }^{38}$ In Making the White Man's West, Pierce notes that in many cases in the wider West boosters took great care to differentiate between desirable and undesirable Europeans. ${ }^{39}$ Boosters in the LRGV nowhere discriminate in print among the various Europeans. Side-stepping common Progressive Era ideas about the relative racial worth of the various European races, the promotional materials lumped Europeans into a single broad category. The literature describes European Americans in a variety of ways: "Americans," "pioneer[s]," "crusader[s]," "colonizers," "colonists," "developers," "thrifty and enterprising people," "prosperous," "Northerners," "big visioned men," "thinking men," "high-type," “successful leaders,"

${ }^{35}$ Montejano, Anglos and Mexicans, 115.

${ }^{36}$ American Rio Grande Land and Irrigation Company, See Texas First, 1930, Box 1, Rio Grande Valley Promotional Literature Collection, 12; Missouri Pacific Lines, The Lower Rio Grande Valley, 1927, Box 2, Rio Grande Valley Promotional Literature Collection, 2; Jackson-Vreeland Land Co., The True Story of the Lower Rio Grande Valley, Texas, 1914, Box 2, Rio Grande Valley Promotional Literature Collection, 9.

37 Wrobel, Promised Lands, 15.

38 Ibid., 167.

${ }^{39}$ Pierce, Making the White Man's West, 151-74. 
"progressive," and "honest to goodness country gentlemen." 40 All these distinctions differentiate the incoming farmers from "the Mexican Peon" rather than from each other.

Bowman's Blood Oranges rightly recognizes that cheap labor was an important selling point in the image of the LRGV constructed in the booster materials. His chapter on the booster materials in Blood Oranges presents a list of six themes in the booster materials but neglects to explore their deep interconnections and mutual articulation; after listing six themes, Bowman reduces the complexity of his discussion to the claim that, "profit, above all, was the underlying concern"-reducing all the other themes to mere means to profit. ${ }^{41}$ This next section aims to consider the themes of land and race as they mutually articulated one another in the South Texas place-myth; race is not reducible to a single cause but rather served many ends. The discourse of race had to frame "the Mexican" to fit a multiplicity of needs beyond merely profit; as we shall see, a narrative had to be constructed that served legalistic, leisure, moral, and social ends as well. The nature of the task was such that a racial other had to be created that justified Anglo supremacy while, at the same time, enabling recuperation of racial others as bodies capable of disciplining into useful workers and docile citizens across the multiplicity of interactions and relationships that would connect them to Anglos. ${ }^{42}$ The promotional materials did this by equating the Mexican with the land, creating analogically exploitable natural resources.

An image from the American Rio Grande Land \& Irrigation Company sales material captured well the portrayal of Mexicans and their ties to the land and nature (see Figure 1). ${ }^{43}$ The background of this image was a mass of unfruitful shrub and dirt.

40 Julia Cameron Montgomery, "A Camera Journey through the Lower Valley of the Rio Grande,” Monty's Monthly News, 1929, Box 1, Rio Grande Valley Promotional Literature Collection; Jackson-Vreeland Land Co., The True Story of the Lower Rio Grande Valley, Texas, 1914, Box 2, Rio Grande Valley Promotional Literature Collection, Library Archives and Special Collections, The University of Texas Rio Grande Valley (hereafter Rio Grande Valley Promotional Literature Collection), 7 \& 9; John H. Shary, The Golden Story of Sharyland, 1941, Box 1, Rio Grande Valley Promotional Literature Collection, 1 \& 8-10; C.E. Barritt, A Call From the Southland, n.d., Box 1, Rio Grande Valley Promotional Literature Collection; Southwestern Land Company, In Rio Grande Valley Paradise, 1930, Box 1, Rio Grande Valley Promotional Literature Collection, 2 \& 11-13; Missouri Pacific Lines, The Lower Rio Grande Valley, 1927, Box 2, Rio Grande Valley Promotional Literature Collection, 3 .

${ }^{41}$ Bowman, Blood Oranges, 70.

${ }^{42}$ In Blood Oranges, Bowman devotes a whole chapter to how South Texas came to resemble the Jim Crow south in the 1920's. Strange then, given his broad knowledge of the impact of race on society in the LRGV, that he remained committed to his thesis that the racism of South Texas was reducible to the exploitation of labor on the colonial model. While exploiting the labor of Mexicans was certainly a primary motivation for the construction of a racial hierarchy, it was not the only motivation. As we have argued and elaborate through the rest of this article, race served a wide variety of ends.

${ }^{43}$ American Rio Grande Land and Irrigation Company, See Texas First, 1930, Box 1, Rio Grande Valley Promotional Literature Collection, 12. 


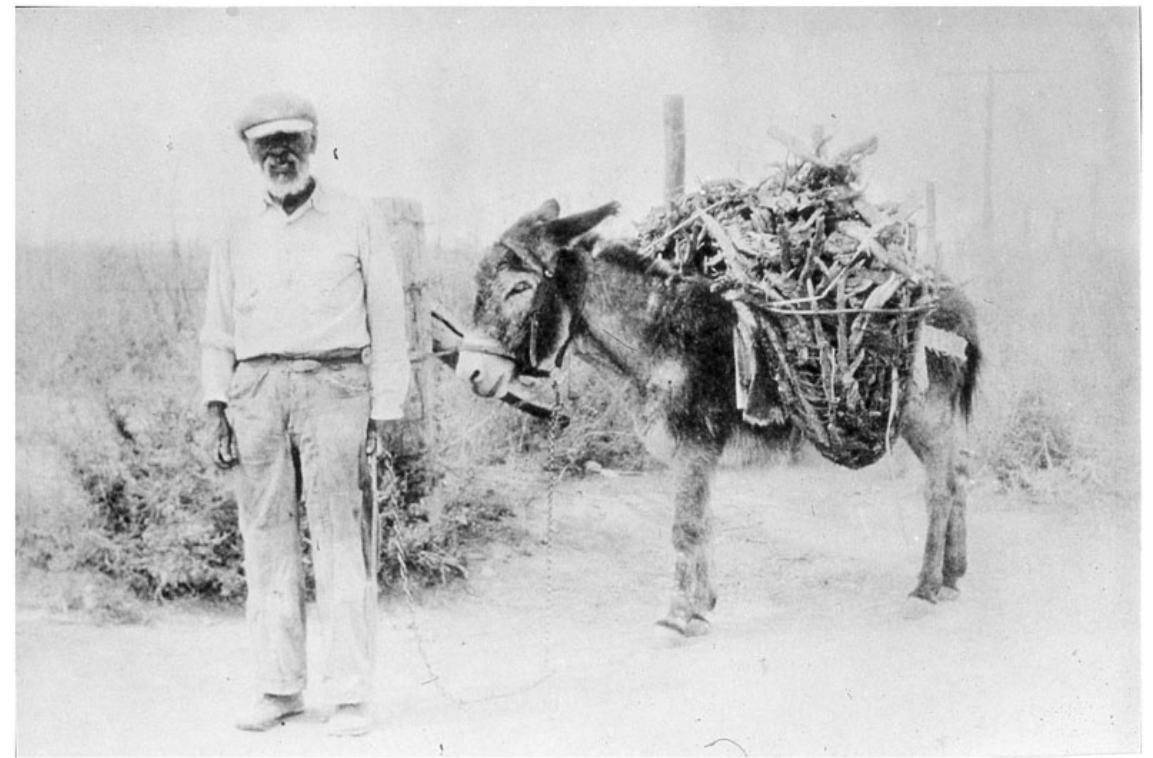

Figure 1. "Mexican Peon.” Illustration in American Rio Grande Land and Irrigation Company, See Texas First, 1930, Rio Grande Valley Promotional Literature Collection, Box 1. Photo courtesy of The University of Texas Rio Grande Valley Library Archives and Special Collections.

The vegetation and lighting in the image presented a dry, hot, desert-like climate. Residing in these conditions were the two primary elements of the piece: a Mexican and a donkey. The donkey appeared to be a calm, complacent creature led by an old rope while carrying the load of the day's work on its back-a pile of debris. The master of this animal was presented similarly to the donkey: as the animal naturally spent its day forging for weeds and grass, this Mexican man seemed to do the same. With a rope in hand, he stood in simple work garments, with a complacent-looking expression and posture. This photo in the sales brochure introduced the northerner to the Mexican population of the LRGV and conveyed directly that the land was being unprofitably used by a people who, like the donkey, spent their days rooting about for whatever minor bounty nature spontaneously provided.

Accompanying this image was a short text that confirms this interpretation of the racialized figure of the Mexican: "The Mexican Peon of yesterday was innately a gleaner. The present generation takes advantage of our modern schools and many of them are high school graduates. With an education they make excellent tradesmen and citizens." 44 The use of the word "gleaner" is of particular interest as it summed up 
what was "innately" the essence of Mexicans. A gleaner is someone who "gather[s] or collect[s] in a gradual way" or who "gather[s] grain or other material that is left after the main crop has been gathered." 45 The "Mexican Peon" was viewed as a gleaner like the donkey and in fact like most animal species. Just as most all nonhuman species survived by gleaning, so too did the Mexican. The photo served as a means to dehumanize Mexicans by associating them with the animal and the natural. The text generalized the qualities of the Mexican man in the photo to all Mexicans, claiming that scavenging among the leavings of nature was the "innate" behavior of the "Mexican Peon." The natural and animalistic gleaners who populated the area explained its current unprofitable and therefore unappealing state. The caption also looked forward to the future of the "Mexican Peon" in "our modern schools." The perspective of "the Mexican Peon" was never taken in the first person in the literature-it was always a racial other that was spoken about from an Anglo perspective. Nevertheless, even given this permanent racial demarcation and hierarchy, the literature did grant Mexicans some mobility within the northerners' order as "excellent tradesmen and citizens" - with the important caveat that they were innately gleaners who would be happy to live off of the leavings and scraps of their bosses.

A promotional magazine entitled In Rio Grande Valley Paradise echoed these points. This magazine informed its audience that "The past years have wrought a miracle in the Valley. From a few thousand people, mostly Mexican, living in clusters of "jacals," the section now has a population of over 200,000 persons. . . the progressive, liberal, enterprising and thrifty people of a dozen middle western states." $46 \mathrm{~A}$ jacal is a hut made up of found materials: mostly sticks, mud, and grasses, and resembles a primitive adobe. In Rio Grande Valley Paradise only ever used the term "house" to describe northern immigrants' dwellings, while it always described Mexicans as living in something other than houses. The use of the word "cluster" in describing the jacals is of particular interest because of its contrast in the booster materials with the depiction of northerners' gridded and orderly organizational systems. As this article's last section will discuss, northern immigrants' houses, orchards, roads, and institutions were shown in gridded and disciplined spacing, rationally ordered and never randomly clustered. What were clustered were the "Mexicans," their jacals, and the random piles of debris and shrubs shown in the photos of unimproved South Texas. The sense of the passage was that Mexicans populated the land like animals, sparely clustering in natural dwellings, gleaned from the materials available in the environment without transformative labor or "enterprise."

${ }^{45}$ Merriam-Webster, “gleaner,” accessed 4 May 2017, https://www.merriam-webster.com/ dictionary/gleaner.

46 Southwestern Land Company, In Rio Grande Valley Paradise, 1930, Box 1, Rio Grande Valley Promotional Literature Collection, 11. 


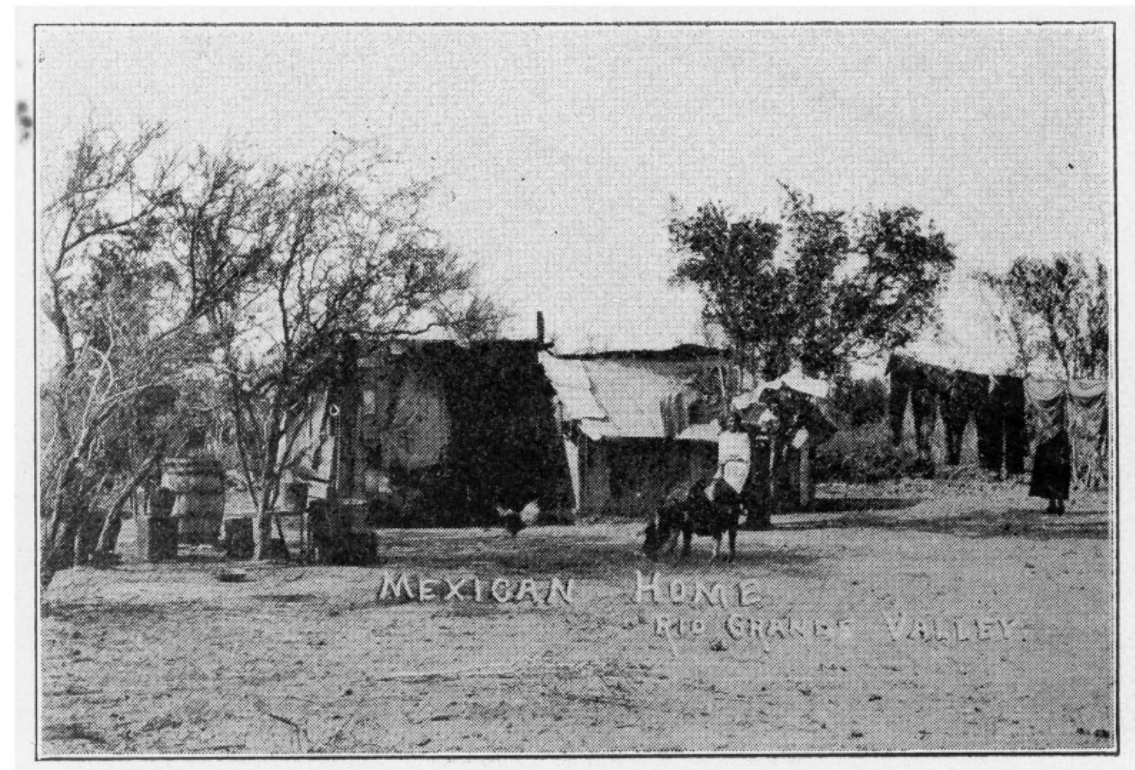

Figure 2. "The Mexican Home: Rio Grande Valley." Illustration in McAllen Chamber of Commerce, McAllen Texas, The City of Palms, 1927, Rio Grande Valley Promotional Literature Collection, Box 1. Photo courtesy of the University of Texas Rio Grande Valley Library Archives and Special Collections.

It is important to note that the dominant image of the Mexican as of a kind of gleaner that meandered according to no progressive or disciplined scheme was mirrored in the descriptions of land and especially the Rio Grande River. For instance, in a small booklet titled McAllen, City of Palms, the depiction of the Rio Grande in its natural state was linked with Mexicans. The booklet showed a series of four images bordering a central text (see Figure 3). The layout of these images formed a sequential and historical narrative about the river reading from left to right and top to bottom. The first of these four images depicted an aerial view of the Rio Grande River as it carved its way across the valley in a winding pattern that dwarfed the elements surrounding it. The aerial view of the river served to instill in the viewer a sense of its tremendous size and inexhaustibility. However, aside from demonstrating the size of the river, the image presented to the reader the natural tendency of the river to wind and meander. This image showed the massive power of the river, yet untapped and undisciplined, waiting to be harnessed. The neighboring text read, "The Rio Grande, pictured from the air on this page, has indeed proved a river of flowing gold. For untold centuries, it has been slowly building a delta of marvelous fertility. Through the ages this delta has been fertilizing itself by producing such vegetation as thrives in semi-arid country. It remained for man to bring the water 


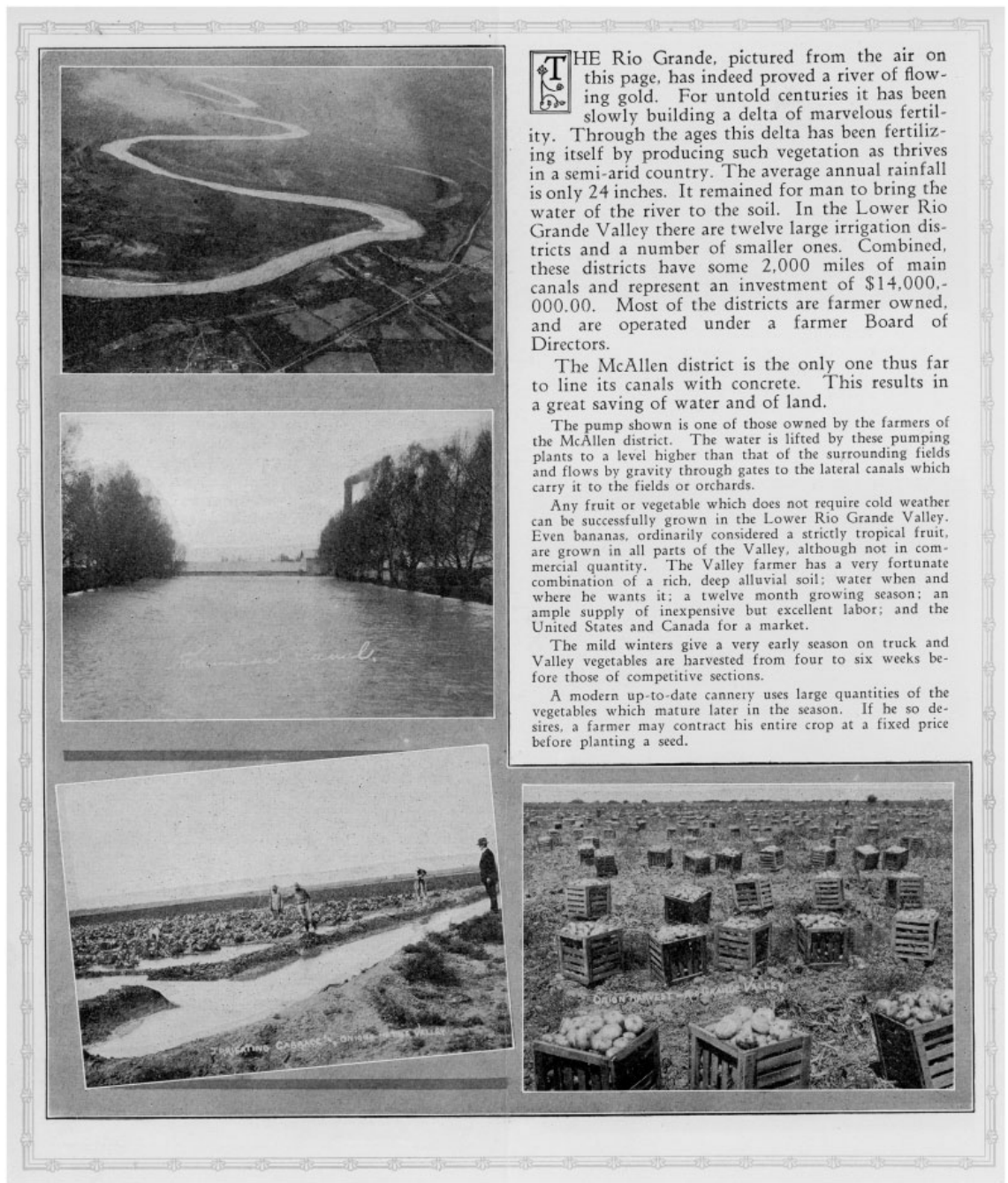

Figure 3. "Narrative of Progress." Illustration in McAllen Chamber of Commerce, McAllen Texas, The City of Palms, 1927, Rio Grande Valley Promotional Literature Collection, Box 1. Photo courtesy of The University of Texas Rio Grande Valley Library Archives and Special Collections.

of the river to the soil." 47 The Mexican was narratively linked to the river in two ways by this image and the text. First, Mexicans were notably excluded from the category of "man." Native Americans, Mexicans, and then Tejanos had

${ }^{47}$ McAllen Chamber of Commerce, McAllen Texas, The City of Palms, 1927, Box 1, Rio Grande Valley Promotional Literature Collection, 3. 
collectively inhabited the region for thousands of years but they had failed to do what "man" does, which is to "bring the water of the river to the soil." The description also analogically linked the exploitation of the river and farmland to "gold": just as was the case in South America, where the indigenous people sat on great wealth but were unable to recognize it and mine it, so too the Tejanos sat on the river and farmland but were unable to recognize and use it. The winding river and its wasted bounty offered evidence that no true men had inhabited the LRGV as construed in the booster literature: men were apparently defined by the employment of reason, initiative, and technology in pursuit of profit. Second, the meandering and undisciplined nature of the river mirrored similar descriptions of Mexicans across the booster literature.

The second image showed the water and silt of the river flowing down a canal, its path engineered efficiently narrow and straight to its destination. This photo, in which the river had been tamed and made available to the progress of civilization, was captioned "water when and where he [the farmer] wants it." 48 The third image was set in the corner of a large field split by a small channel of water. On the foremost left-hand side were three Mexicans laborers looking down and focused only on what was immediately laid out before them on the ground. On the opposite side of this division was the clean and well-dressed land owner gazing into the distance. This individual was overseeing the entire operation and was responsible for the productive employment and harnessing of not only the Rio Grande but also the local Mexican population. The same operation that productively harnessed the land and directed the river also harnessed and directed Mexican labor. The narrative culminated in the fourth image depicting the rich yield of the land. This image depicted the abundance and profit that derived from the "desire and initiative" of "Americans" disciplining the river, the soil, and the "Mexican Peon"-in other words, disciplining nature-through the application of reason and technology. 49

The images were an important part of the discourse produced through the promotional materials. It is hard to completely understand the racial identities established through the "cluster" of jacals or the linking of the Mexicans with the wildly oscillating river until one notes how the northern immigrants were comparatively framed. The work of LRGV immigrants was depicted through gridded, disciplined, and organized uses of space. In the magazine In Rio Grande Valley Paradise, Sharyland the cover presented the viewer with the imagined future of the area should it come under the productive and disciplined organization of "progressive" and "thinking men." The illustration was an imagined aerial view of orderly rows and columns of crops and citrus trees, evoking notions of productivity, order, security, regularity, and discipline over

48 Ibid.

${ }^{49}$ American Rio Grande Land and Irrigation Company, See Texas First, 1930, Box 1, Rio Grande Valley Promotional Literature Collection, 12. 


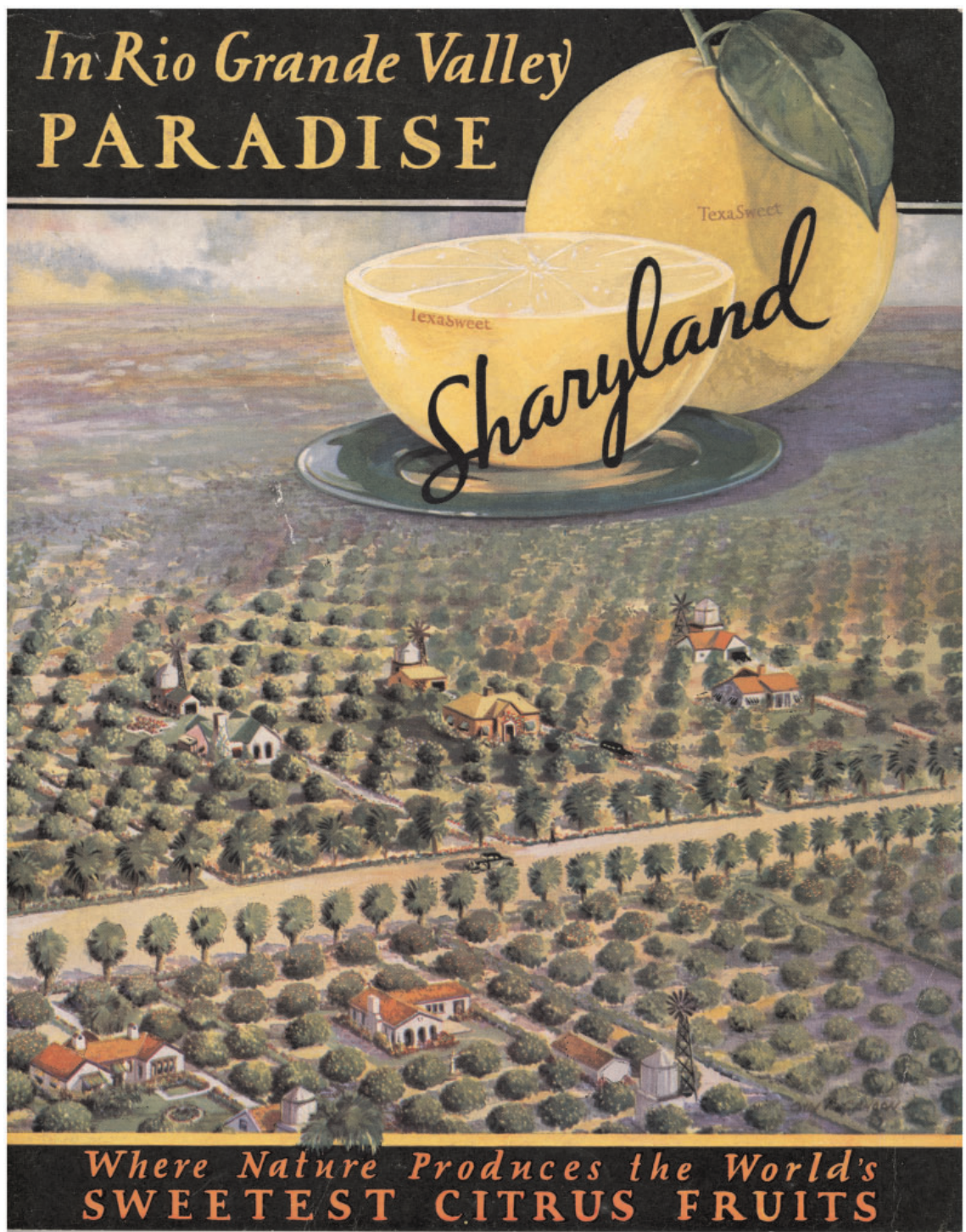

Figure 4. "Imagined Future." Cover of In Rio Grande Valley Paradise, 1930, Rio Grande Valley Promotional Literature Collection, Box 1. Photo courtesy of The University of Texas Rio Grande Valley Library Archives and Special Collections.

the natural forces of land, water, and labor. No longer was the land littered with masses of dry shrub and cactus and randomly dotted with clusters of mud huts but rather the gridded profit-bearing trees and crops were regularly intersected by paved roads and planned infrastructure. These grids provided clear boundaries for property rights, 
provided efficient controlled channels through which capital could travel, and through social institutions, provided for the proper racial and class relationships. The old, chaotic, and meandering ways were erased by the modern, ordered, and productive practices of the "progressive intelligent good people." 50 As discussed in the final section of this article, this linking of northerners with images of gridded and disciplined space was common across many areas of life in the boosterism literature.

In sum, others like Dewey and Bowman have noticed that the promotional materials established a place-myth about the LRGV that emphasized White supremacy and Mexican subservience. This discursive analysis of the promotional materials adds to those findings by showing how "the Mexican Peon" was not an isolated figure in the booster materials but was discursively linked to the ways in which the animals, water, and land - in short nature - were framed in the literature. Just as the plant seeds fertilized where they blew, the animal followed its nose, and the river followed the path of least resistance, so too the "Mexican Peon" gleaned his existence by picking up whatever was immediately at hand. The booster materials placed this bounty-so far untapped by "man" - squarely in the hands of the northern immigrant who would bring himself to bear on reaping its bounty.

In the LRGV and across the West, booster materials promoted the supposedly inferior races as low-cost sources of labor, as Dewey, Bowman, and Wrobel have shown. ${ }^{51}$ An illustrative discussion of race and labor in the LRGV comes in the following passage from The True Story of the Rio Grande Valley:

One of the greatest assets in the valley is our cheap Mexican labor. This labor comes across the river from Mexico, by the hundreds and thousands. We are enabled to hire them for but a fraction of the cost of what northern labor would cost. This enables us to clear our lands and farm them at a lower price than can be done elsewhere in the United States.

This Mexican labor, when directed by our people, is most satisfactory. Our settlers generally select the Mexican families they need to do their work, furnish them some cheap material, with which they erect their own houses and board themselves, relieving the housewife of this trouble and expense. They live very cheaply, the man doing the farm work for from sixty to seventy-five cents per day, while the Mexican woman will assist the housewife with her duties at a very low cost. The entire Mexican family, man, wife and children are always eager to work. Thus, we are enabled to clear up our lands, plant and harvest

50 W.M. Sparrow, Selling Irrigated Farmland, n.d., Box 2, Rio Grande Valley Promotional Literature Collection.

${ }^{51}$ Wrobel, Promised Lands, 168 and 176. 
our many crops and market same at a much lower price, and with much more satisfactory labor than is had elsewhere. ${ }^{52}$

The passage offered a narrative description of the type of labor that settlers could expect to find in the LRGV. The section described the transformation of the Mexican population from gleaners into a "low cost" and "most satisfactory" labor resource "when directed by our people." The "hundreds and thousands" of Mexican laborers were "always eager to work" and ready to "assist." Investors could purchase an entire family unit with each member of the family being put to work. The men would tend to the fields, the women would assist in house chores, and the children would labor where needed. The promotional material ensured readers that the Mexicans were content with this new reality and were eager to work.

The docility, gratitude, and subservience of the Mexican family of laborers was further reinforced by the suggestion that the Mexican laborers would be happy with the homes they construct for their families if only the landowner could "furnish them some cheap material." This comment reached back to the idea of Mexicans as gleaners, who were adept at making due with the leavings of nature. This thought was further reinforced by noting that employers needed only to pay the bare minimum for labor because "[t]hey live very cheaply," presumably scavenging for what was not provided.

Scholars have not been wrong to recognize the emphasis in the booster materials on the Mexican, here the Mexican family, as a source of cheap labor. But labor was just one instance of a hierarchy that extendeded into almost every other facet of life as well. The mobilization of the raced body of the Mexican was not just as laborer but as a part of the larger bounty of nature whose historically untapped status reinforced Mexicans' status as sub-human and part of nature. Race served as an important element in the larger discourse defining the Rio Grande Valley well outside of labor, impacting the view of nature, progress, and civilized order. The next section of this article shows the impact of race on leisure, religion, beauty, fashion, morality, education, and justice.

During the 1920s, leisure activities became a significant part of American life. An "emphasis on consumption and leisure" in American popular culture, combined with a middle-class interest in attaining a "high standard of living," motivated businesses to supply a variety of activities. ${ }^{53}$ Promoters of South Texas real estate combined this burgeoning interest in leisure activities with a vision of a racially segregated society with policed racial boundaries. These racial divisions were also linked to gender and class in that women and men were largely portrayed as partaking in gender-differentiated activities while the Mexican population was not excluded but recruited as the labor that facilitated Anglo leisure. Booster materials envisioned a Rio Grande Valley that was

52 Jackson-Vreeland Land Co., The True Story of the Lower Rio Grande Valley, Texas, 1914, Box

2, Rio Grande Valley Promotional Literature Collection, 9.

53 Dewey, Pesos and Dollars, 84. 
segregated in leisure, education, religion, and shopping along the lines of race, class, and gender.

Leisure and social activities in the promotional material were often clearly directed along gender lines. One piece of promotional material that made distinctions of race and class while tending to the interests of middle-class women was The True Story of the Lower Rio Grande Valley. ${ }^{54}$ This pamphlet described the state of the churches in the LRGV as follows:

Our settlers coming to this district represent most all of the Northern states, and represent nearly every religious faith. They have organized numerous church societies and organizations, and built houses of worship of all the leading denominations. Generally, the first building erected in one of our new towns is the church. These people are generally of a class that have been successful in the North-people with means, who have been used to the best of society and immediately on their arrival here, proceed to affiliate themselves with some of the different church organizations, and contribute in a substantial way to the building and settlement of this district. ${ }^{55}$

The text anxiously made it clear to prospective land buyers that religious life was segregated by race and class: there were a whole crop of churches built by and for people who were "generally a class that has been successful in the North-people with means, who have been used to the best of society" - just like those prospective buyers reading the pamphlet. This pamphlet assured the women reading it that they could expect a variety of religious communities composed of other well-to-do Whites who had migrated from the north. The True Story of the Lower Rio Grande Valley appealed not only to the women's desire to socialize with other successful Whites but assuaged any fears that moral degeneration might accompany a move into the heavily Mexican South.

The Golden Story of Sharyland depicted the best-angled views of new Catholic, Presbyterian, Christian, and Methodist churches in order to highlight the racially and morally upstanding (segregated) nature of the Lower Rio Grande Valley's religious institutions. Looking back to the previous sections on land and labor, the reader already has a sense of how Mexican lives and buildings were portrayed as the haphazard creations of unplanned bricolage; the clean, landscaped, and orderly lines of the photographs of the new churches contrasted with those natural features and mirrored those disciplined Cartesian arrays of northern immigrants' housing, farms, and cities.

${ }^{54}$ Jackson-Vreeland Land Co., The True Story of the Lower Rio Grande Valley, Texas, 1914, Box

2, Rio Grande Valley Promotional Literature Collection, 7.

55 Ibid. 


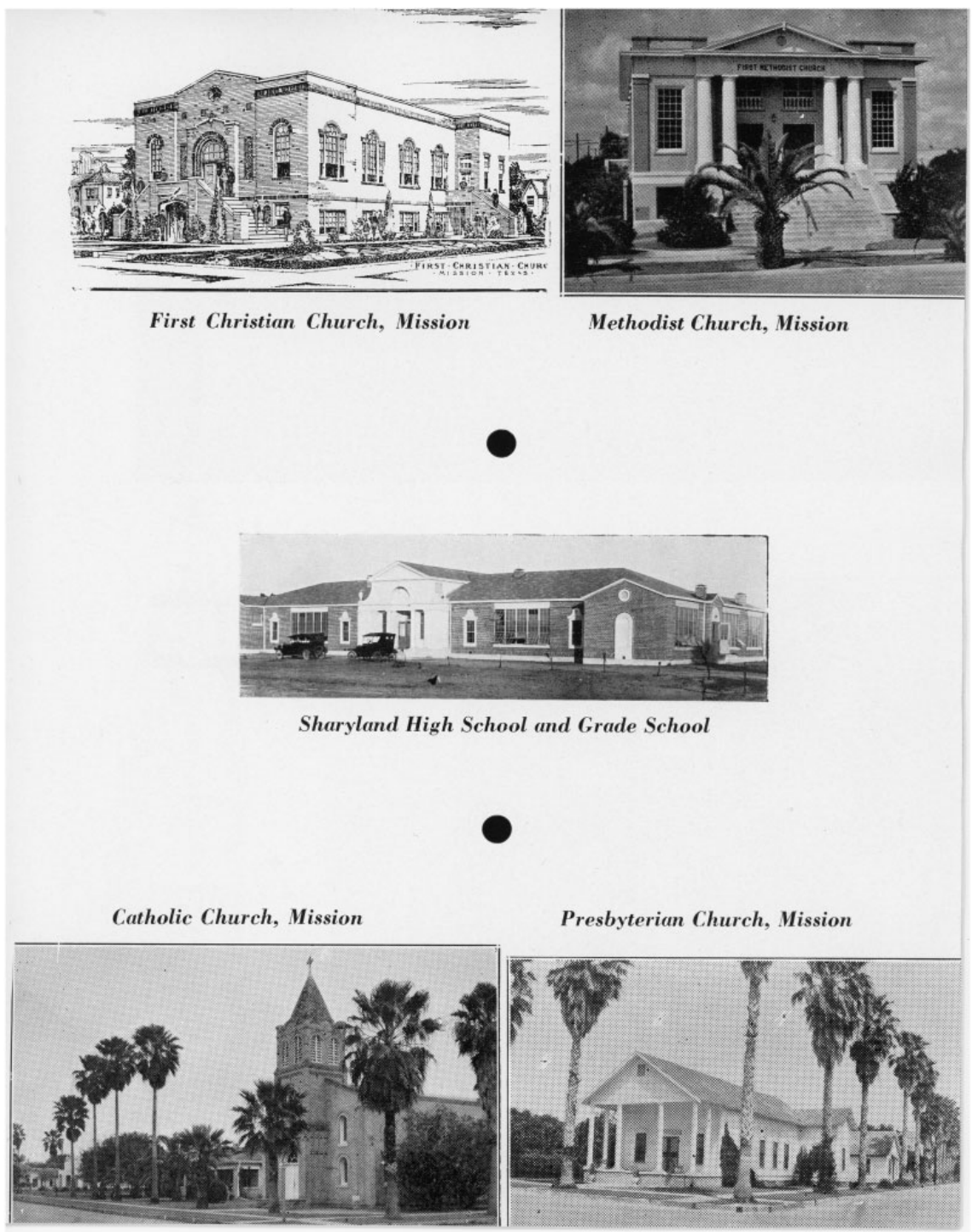

Figure 5. "Churches of the Lower Rio Grande Valley." Illustration in John H. Shary, The Golden Story of Sharyland, 1941, Rio Grande Valley Promotional Literature Collection, Box 2. Photo courtesy of The University of Texas Rio Grande Valley Library Archives and Special Collections.

The same fears that linked racial mixing and moral contagion in the discourse on religion were also echoed in the presentation of schools in the LRGV. The passages on the schools made clear that new institutions built by and for "Northerners" were ready 
for their children. Looking again to The Golden Story of Sharyland, Sharyland High School and Grade School were given center billing in the pamphlet with a large pictorial layout. All the school buildings pictured in this pamphlet and others showed newly built schools with well-kept lawns and a minimal and orderly style of landscaping similar to that of the churches. ${ }^{56}$ These images presented pristine, costly, and ordered educational institutions that had been newly made for the arriving Northern "intelligent good people." 57 The Lower Rio Grande Valley explicitly described the patrons of the LRGV's new moral and educational institutions as an elevated type of being, drawn in from the northern parts of the United States. The text read, "The Valley is unique in that it is populated by men and women who formerly were successful leaders in other parts of the country. That it has attracted an unusually high type of citizenship cannot be doubted after inspection of the Valley's churches and schools." ${ }^{58}$

The desired effect of the educational and religious sales materials was to give women entrusted with their family's moral and intellectual education the impression that the LRGV had become civilized and safe for families and for the rearing of moral, intelligent youth. This religious and educational segregation would grow in time at the insistence of these White settlers to include a larger segregation spanning almost the entirety of the public sphere: "Often, Mexican Americans could not commingle with whites at barbershops, restaurants, funeral homes, churches, juries, theatres, or numerous other public places." 59 White segregation and supremacy in the LRGV was not just about the extraction of surplus value but about the creation of a moral and educational elite that could be differentiated from Mexicans not just in terms of dollars but in terms of their civilized and refined nature. The land and its order, both before northerners and after, were depicted as a reflection of racial character. For Whites to avoid falling into racial degeneration and gleaning, racial purity had to be ensured. These churches and schools were institutions made to continue and perpetuate these differences insofar as they were directed at the next generation, the children of the settlers.

The depiction of the justice and court system also followed along the lines of the churches and schools, dealing with related moral issues of justice and law. "Typify" was

\footnotetext{
${ }^{56}$ Montgomery, “A Camera Journey Through the Lower Valley of the Rio Grande,” 40-3; American Rio Grande Land and Irrigation Company, See Texas First, 1930, Box 1, Rio Grande Valley Promotional Literature Collection, 35 \& 37; John H. Shary, The Golden Story of Sharyland, 1941, Box 1, Rio Grande Valley Promotional Literature Collection, 15; Missouri Pacific Lines, The Lower Rio Grande Valley, 1927, Box 2, Rio Grande Valley Promotional Literature Collection, 23-4.

57 W.M. Sparrow, Selling Irrigated Farmland, n.d., Box 2, Rio Grande Valley Promotional Literature Collection.

${ }^{58}$ Missouri Pacific Lines, The Lower Rio Grande Valley, 1927, Box 2, Rio Grande Valley Promotional Literature Collection, 24.

${ }^{59}$ Robert A. Calvert and Arnoldo De León, The History of Texas (Austin: University of Texas Press, 1990), 234-6.
} 


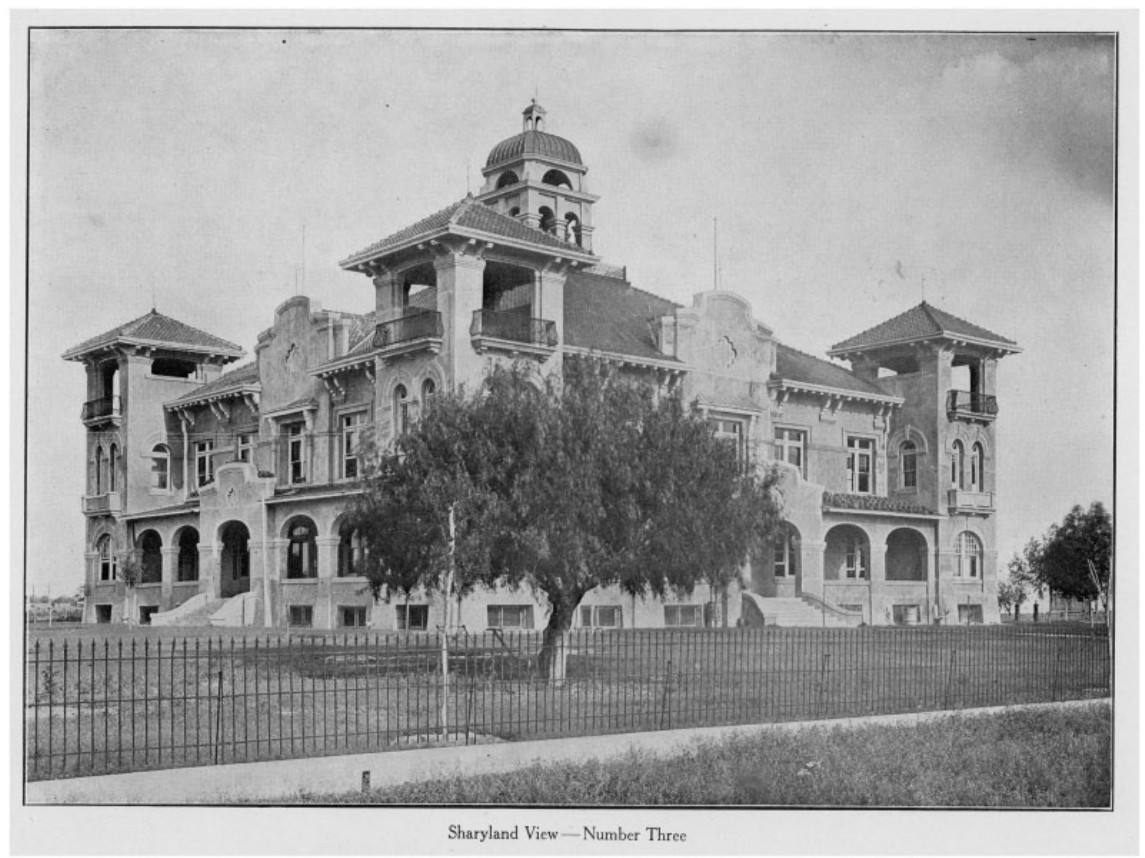

Figure 6. "Typify Courthouse." Illustration in Sharyland Viewbook, 1915, Rio Grande Valley Promotional Literature Collection, Box 1. Photo courtesy of The University of Texas Rio Grande Valley Library Archives and Special Collections.

the byline used to mark the photo of the new Edinburg courthouse in the 1915 Sharyland Viewbook (See Figure 6). ${ }^{60}$ In this context, "Typify" indicated that the new courthouse was typical of the justice system and its improvements in the LRGV since Anglo settlement began in earnest. The text revealed that it cost $\$ 80,000$ to construct the courthouse, then a large sum. Alongside the portrayals of religion and schooling, the emphasis on changes in law enforcement served as further notice to the reader that new institutions of morality, education, and justice had been built to sustain the intellectual, moral, and bodily integrity of the White community not only in this generation but in the next. Given the violence between settlers and Mexicans in Texas due to the 1915 Plan de San Diego uprising and the Mexican Revolution (1910-1920), it is hard not to read this 1915 publication as a promise to permanently keep Mexicans in their assigned place. ${ }^{61}$

60 John H. Shary, Sharyland Viewbook, 1915, Box 2, Rio Grande Valley Promotional Literature Collection.

${ }^{61}$ For more information on the Plan de San Diego and episodes of violence due to the Mexican Revolution in the LRGV see, Johnson, Revolution in Texas. 
Additionally, beauty was an important dimension of the promotional material. There was significant emphasis on the area as a sub-tropical paradise and there were often illustrations and photos of young attractive women amidst exotic plants like palms, hibiscus, or citrus. The vision of beauty was heavily racialized and images were almost exclusively of Anglos in the literature. ${ }^{62}$ The beauty in the LRGV was European beauty; the association of the young beauties with the landscape reinforced what the rest of the literature already made inversely known through its associations of Mexicans with gleaning - that the new fertility, productivity, and order of the land was the result of northern civilizing influence.

A telling example linking the beauty of the area with the beauty of the northern immigrants can be found in the city of Weslaco's promotional material. In 1929, Weslaco threw its first annual "Weslaco Birthday Party." 63 The promotional material emphasized the style shows that were held to celebrate the city and its beauty. The shows were similar to beauty pageants with the added twist that each contestant represented a particular social club or business and dressed solely in local plant materials like leaves, fruit, and flowers. The entrants from these clubs and businesses were almost exclusively White. Over twenty-five years, only 7 out of 226 participants had Hispanic surnames. ${ }^{64}$ These White women's bodies celebrated their race's fertility on a number of levels: they wore the vegetal fertility that northerners had brought to the region with disciplined and profitable farming enterprises, the womens' bodies were the fruit of previous generations, and their sexuality marked the locus of the future generation of regional overlords.

The promotional material presented men's pursuits outside of work as also racially segregated. Northern men were targeted with images that carefully balanced depictions of the lucrative business opportunities available and the year-round leisure activities made possible by the warm weather. For example, The Beautiful Valley of The Lower Rio Grande of Texas bragged that South Texas is a place "Where work is a pleasure, and where pleasure can be combined with work in all seasons." 65

${ }^{62}$ Much of the promotional literature contains images of women, displayed for their attractiveness. They are almost entirely Anglo women with non-Hispanic surnames. For further examples, see Texas Citrus Fiesta, The Home of the Grapefruit, Mission, Texas-The Golden Spot of the Rio Grande Valley, n.d., Box 1, Rio Grande Valley Promotional Literature Collection, 4; Montgomery, "A Camera Journey Through the Lower Valley of the Rio Grande," 22; Review Printing Company, The Lower Rio Grande of Texas The Magic Valley, 1940, Box 1, Rio Grande Valley Promotional Literature Collection, 71-2, 76, \& 107.

${ }^{63}$ Review Printing Company, The Lower Rio Grande of Texas The Magic Valley, 1940, Box 1, Rio Grande Valley Promotional Literature Collection, pg. 71-72; Alicia A. Garza, "Weslaco, TX," Texas State Historical Association Online, accessed 5 May 2017, https://www.tshaonline.org/handbook/online/ articles/hew04.

64 "Agricultural Design: Creating Fashion from Fruit, Vegetables, and Flowers," The Portal to Texas History, University of North Texas Libraries, accessed 5 May 2017, https://texashistory.unt.edu/ explore/collections/ADCF/.

${ }^{65}$ Missouri Pacific Lines, The Beautiful Valley of The Lower Rio Grande of Texas, 1928, Box 1, Rio Grande Valley Promotional Literature Collection. 


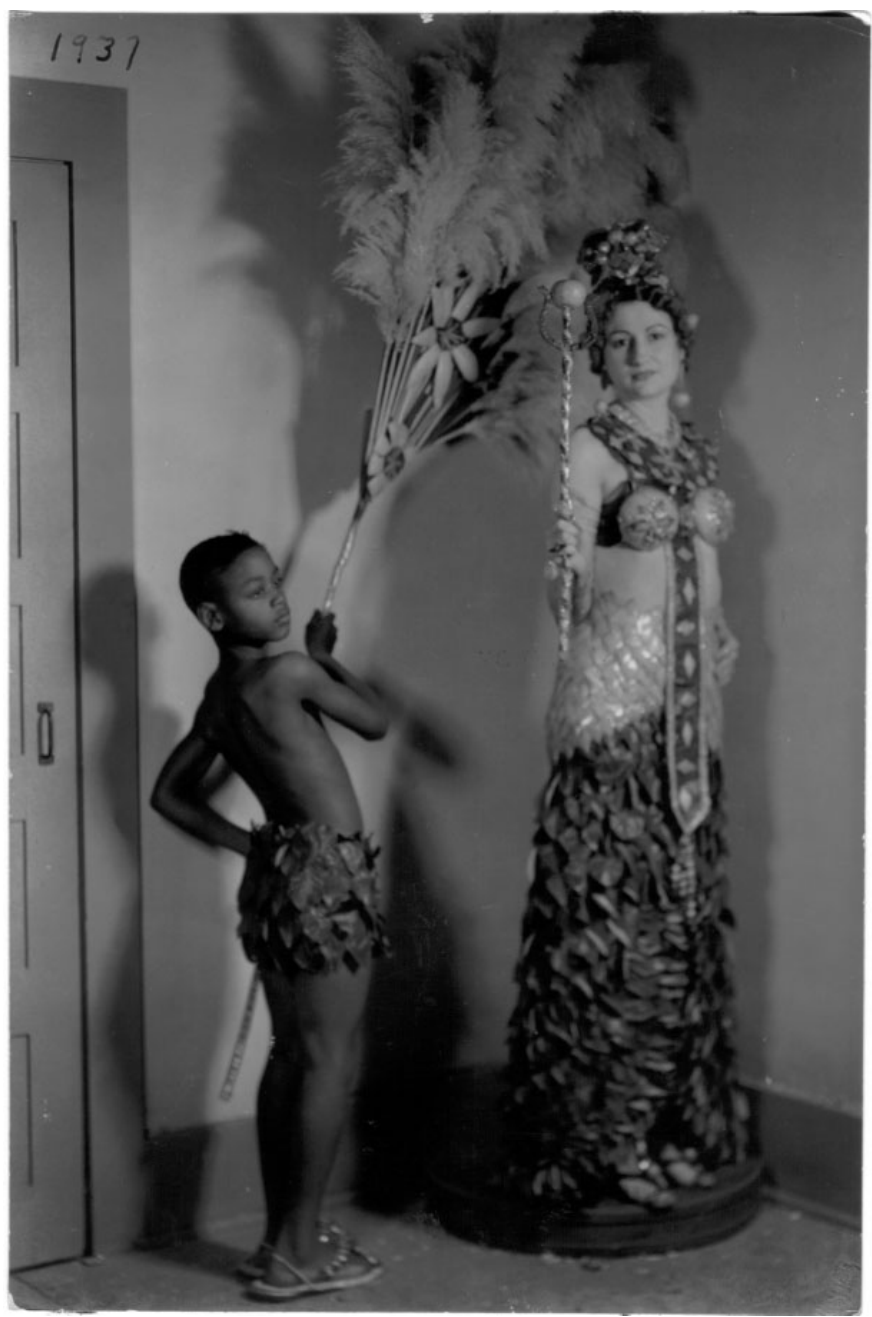

Figure 7. Group Entry in Weslaco's Birthday Party, 1941. From left to right: Miss Kathryn Farina, Mrs. Marie Beeler, Miss Bettie Sue Robinson, Miss Clara Mae Isham, Mrs. Frank Dorsey, Miss Dorothy Hager, and Mrs. Virgil Lehman. "Group Photo," Weslaco Museum. Photo courtesy of University of North Texas Libraries, The Portal to Texas History, accessed 29 September 2017, texashistory.unt.edu/ark:/ 67531/metapth21248/.

Another piece of promotional material called on sportsmen to visit the Rio Grande Valley to fish and hunt in areas that had "never been hunted extensively," apparently not counting the Native Americans and their descendants, including the 


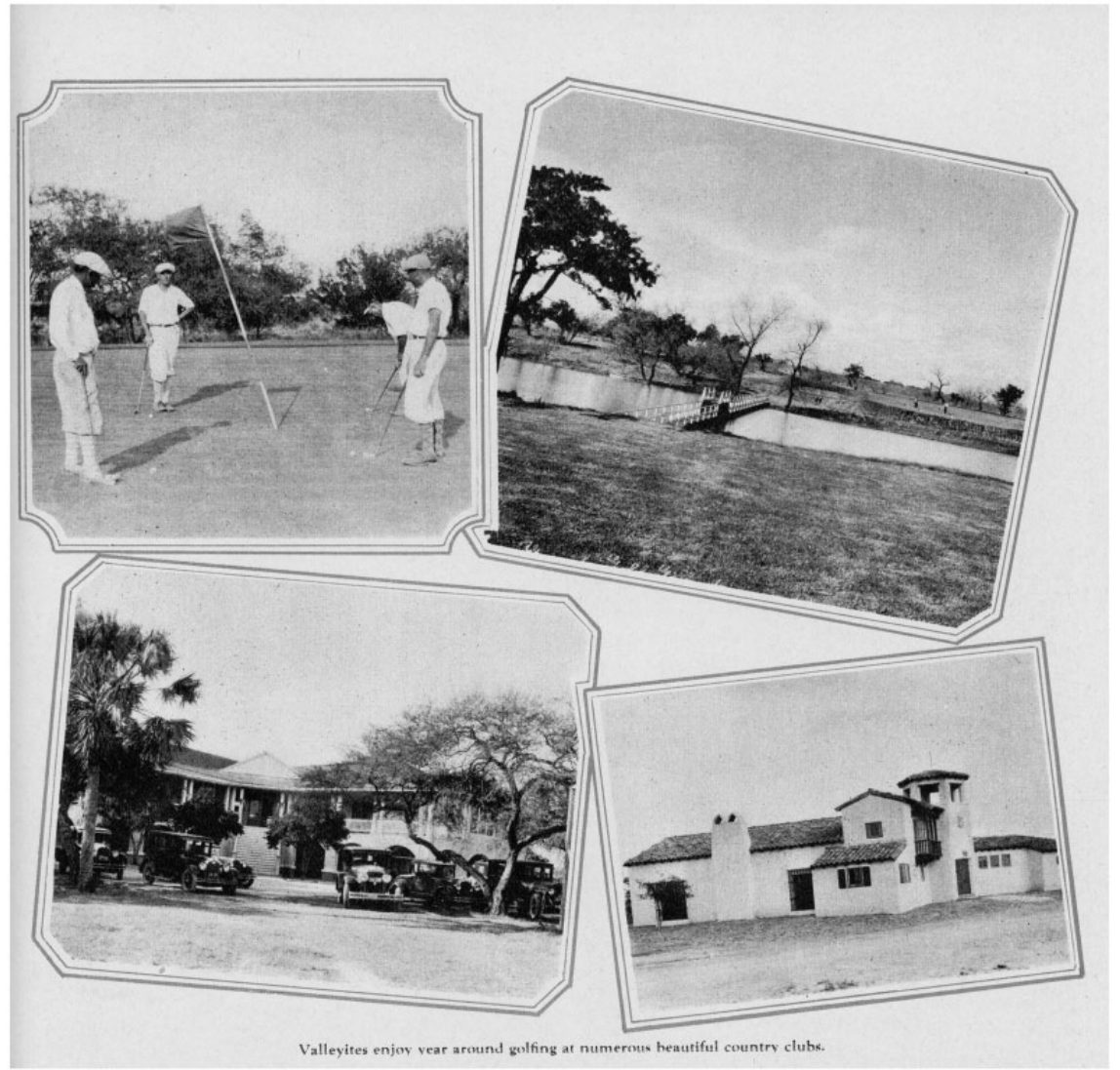

Figure 8. "Work is Pleasure." Illustration in Missouri Pacific Lines, The Lower Rio Grande of Texas, n.d., Rio Grande Valley Promotional Literature Collection, Box 1. Photo courtesy of The University of Texas Rio Grande Valley Library Archives and Special Collections.

Tejanos who had hunted the land for centuries. ${ }^{66}$ This piece describes how one can incorporate hunting with other leisure activities stating, "you can shoot deer in the morning, golf in the afternoon, and billiards at night." These leisure activities were said to be within close proximity to "modern conveniences and luxuries," soothing the reader that they would not have to stray outside of the racial order they had created, even when visiting the wilderness. ${ }^{67}$

The promotional materials did not only create a place-myth based on racial supremacy in labor as other historians have indicated, they also created this myth in nearly every other area of life as well. These racial divisions produced divisions across the social

${ }^{66}$ McAllen Chamber of Commerce, McAllen Texas, The City of Palms, 1927, Box 1, Rio Grande Valley Promotional Literature Collection, 7.

${ }^{67}$ Ibid. 
sphere, aiming at a broad and enduring White supremacy that was able to ensconce itself in luxury and leisure, maintain itself indefinitely through institutions of social reproduction, and celebrate itself through rituals of recognition and commemoration.

This article, backed by previous research showing the effects of the booster materials on shaping conduct and perception in the Lower Rio Grande Valley, focused on the discourse of race produced by boosters. Today, the LRGV continues to impact issues and debates about race in the United States, and so it is imperative to offer a critical eye to the discourses and mythologies that frame race in the region. The discursive analysis of race in booster materials shows that race was not just an isolated element but one that shaped almost every aspect of its construct of place, from land, to beauty, to policing. The discourse on race did much more than just produce Latinos as low-cost labor; it wove together "the Mexican Peon," the soil, and the natural resources of the area and spoke of them as joined by the ethos of the gleaner: meandering bodies who flowed through the path of least resistance, acting only through the opportunities that spontaneously presented themselves. As the "Peon" wandered about in search of the day's lottery of detritus and scavenging, the land hosted whatever wildlife and plants chanced to find a place on it, and the river flowed the irregular and indirect path it found genial, only irrigating the plains around it haphazardly and at inutile intervals. The "Mexican Peon" was not just cheap labor in the booster materials but also part of the natural environment of the Rio Grande Valley that could all be similarly ordered and disciplined by Whites. Race formed a key element of not only who Mexicans were but also what the Rio Grande Valley as a whole was.

The figure of the northerner was joined to images of discipline, regularity, and the scientific maximization of resources. Rows, columns, regular spacing, and the mechanistic division and assignation of time were hallmarks of the portrayal of Anglos and have to be seen in contrast with the area in its natural and "undeveloped" state. The difference in these racial accounts was that the Mexican was shown as simply participating in nature but not ordering or producing it - like the river and the wildlife, the Mexican was thought to follow chance-while the northerner seemingly brought and imposed a mastering discipline that structured life from business to leisure. This racially marked ordering went well beyond economic order and found expressions in morality, religion, education, leisure, shopping, and justice as well. Race was coincident with an economic division of labor in the place-myth of the LRGV, but it was also much more than that; it was tied into its very being, from its physical arrangement to the relationship of the things inhabiting it. Race was an ontological element in the promotional literature, not just an economic one: race was discursively linked to every area of life.

The West, explains Pierce, worked as a "dream of a white refuge" that "never fully died." 68 The dream of the Magic Valley shared in that racialized vision of paradise with the rest of the western booster materials insofar as it made glowing promises about

${ }^{68}$ Pierce, Making the White Man's West, xii. 
the abundance of the area and offered a racially stratified vision of life. But it also differed in ways that brought it closer to the South than to California and other parts of the West. Whereas Californian booster materials reflected a host of non-White racial and ethnic divisions (Native Americans, Black, Japanese, Mexican, and Chinese) and divisions within Whiteness reflecting the relative social ranking of various Europeans, the discourse produced in the LRGV was racially simplified in a way similar to Jim Crow. In the booster materials, there are only northerners, who encompassed an undifferentiated body of Europeans, and Mexicans, which gathered Tejanos, Mexican immigrants, Mestizos, and Indigenous people_-lower and upper class alike_-into one blunt grouping. Also like Jim Crow and unlike some booster materials that focused only on economic opportunity, the booster materials of the LRGV offered a systematic form of segregation that extended the length and breadth of society, forming a holistic system of oppression and exploitation tied into an ontological account of race. 